which was followed in 1896, by a complete edition and translation, Inscriptions de l'Orkhon déchiffrées par Vilh. Thomsen, published by the Finno-Ugrian Society in Helsingfors.

It was the work of a genius which was here given to the world, comparable only to the discoveries which led to the reading of the hieroglyphs and the cuneiform inscriptions, and in Thomsen's case it was brought to completion by a single man and was not the result of the combined efforts of several scholars. The records read by Thomsen were not of the same importance for the history of human civilization as the Egyptian and cuneiform texts, and the world at large has not, therefore, taken such an interest in his discovery as in those of his predecessors. But his achievement is in no way inferior to theirs, and he will always be remembered as one of the greatest scholars of all times.

I shall not try to analyse his remaining works. ${ }^{1} \mathrm{He}$ wrote about Scandinavian and Romance languages, about Cyprian, Lycian, Etruscan, and Kolarian, and in lectures in the University and in learned societies he discussed various linguistic and historical problems, always with the same sobriety, methodical stringency and insight, and with the same wide horizon, which took in the different sides of every question.

Denmark has fostered a long series of illustrious philologists, of whom any country might be proud. But there is none whose name shines in brighter splendour than Vilhelm Thomsen's.

Sten Konow.

\title{
B. L. Rice
}

By the death of Mr. Benjamin Lewis Rice, C.I.E., who passed away in July last, the Royal Asiatic Society has lost one of its oldest members (he was elected in 1879) and Indian studies a pioneer worker of acknowledged merit. His father,

1 They can now be consulted in a splendid edition, Samlede Afhandlinger, Copenhagen and Kristiania, 1919-22. 
Benjamin Rice, was an agent of the London Missionary Society, who laboured with ability and success in Southern India and produced numerous useful Kanarese works, both original and translations, for the purpose of religious and secular education; and here Benjamin Lewis Rice was born on the 17th July, 1837. After a few years passed in the commercial world of London, he went out in 1860 to Mysore, where he held the posts successively of head master of the Central High School at Bangalore, Inspector of Schools in Mysore and Coorg (1865-8, 1870-3), Director of Public Instruction in the Mysore State (1868-9, 1873-83), Secretary to the Education Department of the Mysore Government (1883-90), and Director of Archæological Researches in Mysore (1890-1905), besides serving in 1882-3 as secretary to the Commission on Education of which Sir W. W. Hunter was president. He finally retired from official duty in 1906, and spent the remainder of his life in Harrow. He particularly distinguished himself by the large number of useful works on the history, antiquities, social conditions, and language of the Kanarese country written or edited by him, of which the most notable are the Mysore Gazetteer, edited by him in 1877-8 (of which a revised and enlarged edition appeared in 1897); the Mysore Inscriptions, translated by him for the Government in 1879 ; his Census Report on Mysore, published in 1881 ; the Bibliotheca Carnatica, a series of classical Kanarese works on poetry, grammar, and rhetoric edited by him, beginning in 1884; his Catalogue of Sanskrit Manuscripts in Mysore and Coorg, published in 1884; the Epigraphia Carnatica, edited by him in 1886 and later, which contains the texts and partial translations of the inscriptions of Mysore State with introductions and includes a number of important records discovered by him; his Coorg Inscriptions, which appeared in 1886 (a second edition of Part I was issued in 1914), and his Mysore and Coorg from the Inscriptions, a summary of the historical data furnished by the Epigraphia Carnatica, which he produced in 1909. A man of untiring 
industry, wide learning, and earnest devotion to the pursuit of truth, he has rendered exceedingly great services to the cause of knowledge by the stimulus which he has given to historical and literary studies in Southern India.

L. D. BarnetT.

\section{J. Estlin Carpenter}

By the death of J. Estlin Carpenter, D.Litt. and D.D. (Oxford), Hon. D.D. (Glasgow), D.Theol. (Jena and Geneva), which occurred on 2nd June, the Society loses a distinguished member, and Oxford society a highly respected and dearly loved figure. Dr. Carpenter, who was born in 1844, after holding ministerial appointments in the Unitarian community at Clifton and Leeds, accepted a lectureship at Manchester College in 1875, and was Principal of that institution, by then established in Oxford, from 1906 to 1915. His interest lay chiefly in natural and comparative religion, of which he was appointed to the Wilde Lectureship at Oxford in 1914. He took a prominent part in organizing the Third International Congress for the History of Religions which met at Oxford, 15th to 18th September, 1908, and greatly contributed to its success. His interest in these matters led him to study various Oriental languages and indeed profoundly. He wrote on Pentateuchal Criticism, of which he is by some authors (e.g. Mr. Harold Wiener) treated as a leading exponent; he collaborated with Professor Rhys Davids in editing Buddhistic texts and was one of the recognized authorities on Pali ; he wrote on the Synoptic problem, and on Theism in Mediaeval India. He translated Tiele's standard work on the History of Religion, and edited the translation of Ewald's History of Israel, a work which is now almost forgotten, but which exercised great influence in its time, though probably rated at its true value by Bishop Colenso.

As principal of Manchester College he won the warm affection and admiration of his students, many of whom have acquired fame. He extended its hospitality to representatives of 